\title{
Strategic Orientation on Performance: The Resource Based View Theory Approach
}

\author{
Raymond Dionysus and Agus Zainul Arifin \\ Magister Management Program, Tarumanagara University, Jakarta, Indonesia \\ Email:agusz@fe.untar.ac.id
}

\begin{abstract}
This study aims to verify of the relationship between Entrepreneurship Orientation and Market Orientation to Small and Medium Enterprise (SME) Performance, using the Resource Based View (RBV) theory approach. The research object used was SME entrepreneurs in DKI Jakarta. This research uses a quantitative research design. The data used in this research consists of primary data and collected through Google Forms, which are distributed online. The amount of data collected was 190 samples. The collected data will be analyzed using SEM-PLS Version 3.3.2. Statistical analysis test the outer and inner models. The results obtained indicate that Entrepreneurship Orientation plays a role in SME Performance, and Market Orientation does not affect SME Performance. The implication of this research shows that the Resource Based View theory is right to explain the relationship between Entrepreneurial Orientation and SME Performance because SME performance will be better if it has Entrepreneurial Orientation.
\end{abstract}

Keywords: Entrepreneurial Orientation, Market Orientation, Firm Performance, Small Medium Enterprise.

\begin{abstract}
Abstrak: Tujuan penelitian ini untuk memverifikasi hubungan antara Entrepreneurship Orientation and Market Orientation terhadap Kinerja UMKM dengan pendekatan teori Resource Based View (RBV) theory. Objek penelitiannya adalah pemilik usaha UMKM di wilayah DKI Jakarta. Penelitian ini menggunalan disain penelitian kuantitatif. Data yang digunakan adalah data primer dibuat dengan aplikasi Google Form dan didistribusikan secara daring. Data yang terkumpul sebanyak 190 sampel. Data dianalisis dengan pendekatan PLS-SEMHasil penelitian membuktikan Entrepreneurship Orientation berpengaruh positif terhadap kinerka UMKM, tetapi Market Orientation tidak berpengaruh signitfikan terhadap kinerja UMKM. Implikasi dari penelitian ini menjelaskan bahwa Teori RBV mampu menjelaskan dengan baik hubungan antara Entrepreneurship Orientation and Market Orientation terhadap Kinerja UMKM, sehingg kinerja UMKM akan menjadi lebih baik dengan keberadaan Entrepreneurial Orientation.
\end{abstract}

Kata kunci: Entrepreneurial Orientation, Market Orientation, Firm Performance, Micro Small Medium Enterprise. 


\section{INTRODUCTION}

Small, and Medium Enterprises (SMEs) are one of the economic backbones in many developing countries. The existence of SMEs in Indonesia is considered very important for the national economy because it plays an important role in providing employment, driving regional economic growth, an important player in the development of local economic activities and community empowerment, creating new markets and sources of innovation, and contributing to maintaining the balance of payments. Even when the economic crisis occurred in 1998, it became the main buffer for the collapse of the Indonesian economy. The contribution of the SME sector in 2018 is $60 \%$ of Indonesia's GDP, employs $96 \%$ of the total national employment or 75.33 percent of the total non-agricultural workforce in Indonesia. SMEs have a proportion of $99.99 \%$ of the total business operators in Indonesia. Such a large contribution to the national economy proves the importance and sustainability of Indonesia's SMEs (Indonesia Central Bureau of Statistics, 2019).

The important role of SMEs in the Indonesian economy is not supported by the phenomenon that occurs. Various problems that occur, hamper growth and disrupt the performance of SMEs. Data from the Ministry of Cooperatives Small and Medium Enterprises (2019) have reported that from 2015 to 2018, 1.7 million SMEs in Indonesia went out of business due to low performance. These problems can be divided into external and internal obstacles (Wang, 2016). Most internal obstacles occur because of the low quality of human resources in reading market needs, low management ability and slow pace of new technological adoption, the cost of research is almost non-existent for researching and developing new products; weak business networks and weak market penetration capabilities related to marketing capabilities and product quality; the ability of SME entrepreneurs to continue to innovate and the desire to take risks; lack of knowledge about market conditions, company characteristics/orientation (Jatmika, 2016). The external obstacles that arise, such as lack of access to market information, raw materials, and technology to gain market opportunities and enlarge market share (Nuari, 2017). These barriers are evenly distributed in many countries, especially in ASEAN countries. The biggest obstacle is difficult access to obtain loan funds, market information, and marketing skills.

Viewed from the perspective of Resource-Based View (RBV) theory, performance is the manifestation of resources that forms strength and weakness, as well as an organizational or corporate boundary (Wernerfelt, 1984). Resources that have a sustainable competitive advantage and have impact on performance must have four characteristics of VRIN criteria (Valuable, Rare, Inimitable, and Non-substitutable (Barney, 1991). Resources can be classified as intangible and tangible resources. Resources that will produce a performance for the company are resources that can be controlled by the company (Amit \& Schoemaker, 1993). Conceptual framework of Resource-Based View (RBV) is possible to identify company resources that have the potential to be a driver of company performance, by linking resources power, ability, and decisive action with the achievement of sustainable competitive advantages that produce higher profits than competitors (Barney, 1991). The ability to compete from company resources arises if the company can build strategic orientation (Peteraf and Bergen, 2003).

Strategic orientation is one form of intangible resources. The ability of Strategic Orientation is in the form of organizational excellence (Lonial and Carter, 2015). 
Organizational excellence can provide sustainable profits and superior company performance (Zhou et al., 2007). Typologies of Strategic Orientation include Market Orientation (MO), Entrepreneurial Orientation (EO), Customer Orientation, Cost Orientation, Innovation Orientation, Competitor Orientation, Learning Orientation, Employee Orientation, and Interaction Orientation (Ferraresi et al., 2012). Entrepreneurial Orientation (EO) and Market Orientation (MO) are the two main components that are inherent to SME owners and have an impact on performance (Boso et al., 2016). This strategic capability possessed by SME owners is important and has impact on company performance because SME owners have a corporate function attached to one individual, which is to function as the owner and manager of the company. Because these two functions are inherent in SME entrepreneurs causing problems and agency costs can be eliminated because agency problems arise due to the ownership function being separated from the management function through agents (Jensen and Meckling, 1976).

Entrepreneurial Orientation is a view and attitude that underlies the thoughts, concerns, or tendencies that business people have in the practice of strategic decision making, to identify and run a company's business. This attitude is reflected in the company's ongoing processes and culture. The form of attitude can be seen from the high participation of business people to engage in product market innovation, doing rather risky business, when the first time business people come with 'proactive' innovation to defeat their competitors. Another attitude is shown in the form of competitive aggressiveness and autonomy (Dess and Lumpkin, 2005). In many studies, Entrepreneurial Orientation is converted into three dimensions, namely innovativeness, proactiveness, and risk-taking (Covin and Slevin, 1989).

(Omisakin et al., 2016) argue that companies with an competitive-aggressive orientation can revise competition rules, redefine industry boundaries through profits by entering into it, and improve market position. This action enables the company to gain substantial market share, outperform competitors, and increase revenue. Lumpkin \& Dess (2001) describe business people who have an entrepreneurial orientation, will have an aggressive attitude of competitiveness. Business people tend to directly challenge their competitors to gain competitive advantage in the market. The businessman will innovate to use competitive methods that continuously developed. This concept is used to measure how an entrepreneur's company faces threats, and also refers to the company's response to the achievement of performance through competitive advantage.

The results of the study of relationship between Entrepreneurial Orientation on performance show inconsistent results. (Alvarez-Torres et al., 2019) proved that Entrepreneurial Orientation (EO) had positive effect on performance, but one of the dimensions of EO namely Risk-Taking (RT) had negative effect on performance (Rezaei and Ortt, 2018). The results of other studies show different results. Differences are caused by using different dimensions measurement, namely Innovativeness, Proactiveness, Competitive Aggressiveness, Risk-Taking and Autonomy (Alvarez-Torres et al., 2019).

Market orientation (MO) as an organizational culture through efficiency measures to achieve superior market value in the form of improving business performance (Narver and Slater, 1990). MO is part of strategic competencies that can increase market-based resources better (Talaja et al., 2017). The fact shows that market-oriented companies tend to have more new business opportunities and have better performance than companies that are not market-oriented, so this company is superior in competition and leads to profit growth and 
market share (Armstrong et al., 2014). Market-oriented corporate culture is considered as the key to improving business performance because it prioritizes customer needs and focuses on customer satisfaction (Kumar et al., 2011). Thus, market orientation provides a positive relationship with business profitability. Whereas another opinion from (GruberMuecke and Hofer, 2015) states that EO and MO directly and indirectly (through VRIN resources) increase competitive advantage and that competitive advantage leads to higher levels of company performance. Another opinion from (Narver and Slater, 1990) states that the creation of superior customer value is also associated with improved performance and is the key to competitive advantage and performance. Therefore according to (Buli, 2017), SME Managers need to be encouraged to be involved in the MO to respond to customer requests and realize business performance goals. The results of the study demonstrate an inconsistent relationship between market orientation (MO) and company performance, especially SMEs. The results of the study prove that MO has a positive effect on the performance of SMEs (Lekmat et al., 2018; Protcko and Dornberger, 2014). Other studies prove no effect (Buli, 2017; Shehu and Mahmood, 2014).

From the component of entrepreneurial orientation (EO), such as aggressive attitude, involves risk factors, because the entrepreneurial orientation depicts entrepreneurs as rational decision-makers who take risks on business opportunities. Risks occur because decisions made involve high probability of failure (Wiklund and Shepherd, 2003). Risktaking as a company's willingness to seize business opportunities, even though the company does not know whether this business will succeed or not, and the company's willingness to act boldly without knowing the consequences (Matchaba-Hove and Vambe, 2014). Therefore all business decisions involve an element of risk (Deepa and Manalel, 2016).

The purpose of this study is to verify the theory of the relationship between Entrepreneurial Orientation and Market Orientation on the performance of SMEs. Analysis uses the theory of Research-Based View (RBV) approach. The novelty of this research is to verify the theoretical model by combining two studies, namely (Ali et al., 2020) and (Najmi and Abror, 2019), and conducted in 2019 in DKI Jakarta, Indonesia which is a developing country. The sample of this research is SME entrepreneurs in DKI Jakarta. The choice of SME entrepreneurs is because the manager is also the owner, so that agency problems do not occur, thus the performance of SME companies can also be assessed as the owner's performance.

\section{THEORETICAL REVIEW}

Resource Based View Theory. Resource-Based View (RBV) theory was first put forward by (Wernerfelt, 1984), who said that the company is a vast collection of resources, in the form of Tangible or Intangible Assets that are bound to the company. (Barney, 1991) explains that company resources must meet VRIN (Valuable, Rare, Inimitable, and Nonsubstitutable) criteria to achieve sustainable competitive advantage and produce extraordinary performance. (Zhou et al., 2007) states that Strategic orientation is one of the intangible assets owned by a company, which can lead to superior company performance. (Ferraresi et al., 2012) states that the Strategic Orientation consists of seven types of traits, namely Market Orientation (MO), Entrepreneurial Orientation (EO), Customer Orientation, Cost Orientation, Innovation Orientation, Competitor Orientation, Learning Orientation, Employee Orientation and Interaction Orientation. (Runyan et al., 2006) state that for small 
business owners, Entrepreneurship Orientation (EO) is one part of management skills, and is a resource that can provide competitive advantage and can improve small business performance. (Talaja et al., 2017) state that the MO represents strategic competencies that increase better utilization of market-based assets/resources, and the MO directly and indirectly (through VRIN resources) increases competitive advantage and that competitive advantage leads to higher levels of company performance. Whereas (Nguyen, 2018) states that the use of resources such as Management Accounting Systems (MAS) in marketoriented companies, in addition to meeting the VRIN requirements in RBV theory, will enable companies to promote learning and create knowledge so that company performance is superior.

SME Performance. (Westover, 2008) states that Performance is considered as the ability of organizational functions to achieve their goals by utilizing available resources efficiently and effectively. (Borshalina, 2015) herself states that if a company has good performance, then the company can continue to survive, profit and grow. Performance is multidimensional, and from many literature studies, a variety of performance indicators are used when assessing the association between Entrepreneurial Orientation (EO) and Market Orientation (MO) and business performance (Rauch et al., 2009). Firm Performance is usually measured by the owner's perception of the overall performance (Overall Performance), through comparison between organizational performance with company goals (Kirca et al., 2005). This is supported by (Yadav et al., 2019), which states that Firm Performance is an indicator of the achievement of company goals and to measure the performance of SMEs that have different sizes and handle different product categories, therefore it is better to use subjective indicators because it is very difficult to find an objective measure of SME performance in the form of financial statements. The majority of SMEs are not organized and are far from standard accounting and bookkeeping procedures. In addition, according to (Martin and Javalgi, 2016), research on performance is recommended to adopt subjective measurements so as to assess efficiency, effectiveness, and adaptability.

To measure performance subjectively, some previous studies also used profitability, as measured by the Return On Asset ratio, employee growth rate \& Market Share (Gruberand Hofer, 2015); Market Share, Sales Growth and profitability (Sahibzada Jawad et al., 2019); Sales Growth, Profit Growth and Return on Investment (Kocak et al., 2017); Sales Growth, Employment Growth, Gross Margin, Profitability (Buli, 2017); Sales Growth, Increasing the Number of Workers (Employment Growth), Gross Profits Margin (Balodi, 2019).

Entrepreneurial Orientation and SME Performance. Entrepreneurial orientation (EO) is defined as a process of forming a strategy by making the organization have entrepreneurialbased actions and decisions. (Rauch et al., 2009) Businesses with strong EO have better performance (Covin and Slevin, 1989; Wiklund and Shepherd, 2005). EO is categorized as a critical process in organizations that helps companies to survive and improve the performance of their organizations. (Amin et al., 2016) EO is categorized as a critical process in organizations that helps companies to survive and improve the performance of their organizations (Amin et al., 2016; Khalili et al., 2013). SMEs that adopt an Entrepreneurship Orientation do their activities better than others (Semrau et al., 2016). 
Dimensions of Entrepreneurship Orientation, namely Innovativeness, Risk-Taking, and Proactiveness (Miller, 1983). Innovativeness can be interpreted as company's willingness to support renewal, creative processes and the development and growth of new ideas through experiments, which lead to the development of new products, new services, new marketing methods and new organizational methods in the company's business practices (Aladejebi et al., 2018), so companies are guided to become more competitive in the market by providing value to the company and its customers (Balodi, 2019). (MatchabaHove and Vambe, 2014) states that Risk-Taking can be defined as the company's willingness to seize the opportunity, even though the company does not know whether this business will succeed or not, and the company's willingness to act boldly without knowing the consequences. Other opinions from (Mason et al., 2015) states that Risk-Taking can also be identified as a trend that involves taking bold actions against the unknown and utilizing significant resources to conduct business in an uncertain environment. according to (Wolff et al., 2015), Proactiveness is individual behavior that can be shown by facing competitors, through maximizing business opportunities. (Mason et al., 2015) hiSMElf states that Proactive activities also mean looking for opportunities using future perspectives, which are characterized by introducing new products and services and acting as an anticipation of future demand. Whereas (DeepaBabu and Manalel, 2016) argues that proactiveness is related to taking one step ahead of competitors.

(Runyan et al., 2006) and (Ferreira and Garrido, 2008), also stated that Entrepreneurship Orientation (EO) is an intangible resource to achieve competitive advantage and can improve the performance of small businesses. In a highly competitive environment, a strong entrepreneurial spirit in Entrepreneurial Orientation, is an important element that needs to be considered for assessing company performance (Riviezzo et al., 2013). While other opinions say that, when a company decides to exploit new opportunities, which may involve risks as well, must be equipped with capabilities contained in the EO dimensions, so the company can become a proactive and aggressive entity, to achieve competitive advantage against rivals, which which will improve the company's performance (Yadav et al., 2019).

The results of research conducted by (Keh et al., 2007) show that Entrepreneurial Orientation has positive influence on business performance. Besides, a meta-analysis of 51 studies conducted by (Rauch et al., 2009) revealed that the impact of EO on performance was quite large. Research conducted by (Matchaba-Hove and Vambe, 2014) in Eastern Cape, South Africa shows that the dimensions of entrepreneurial orientation (innovative, proactive, and competitive aggressiveness) have a positive effect on business performance, while risk-taking and autonomy do not have a significant effect on performance company. Recent empirical studies show a positive relationship between EO and organizational performance (Campos and Valenzuela, 2013; Buli, 2017; Sahoo and Yadav, 2017). Also, most of previous studies used the Miller/Covin and Slevin concepts and using 3 EO dimensions, namely Innovativeness, Proactiveness, and Risk-Taking to measure the effect of EO on performance (Jogaratnam, 2018; Montiel-Campos, 2018). However, several studies also found a negative or insignificant relationship between EO and Performance (Affendy et al., 2015). Based on a theoretical study and relevant research results, a hypothesis was built:

Hypothesis 1: Entrepreneurial Orientation has positive effect on SME Performance. 
Market Orientation and SME Performance. Market orientation is the most efficient and effective organizational culture for creating the behaviors needed to create the best value from customers and superior performance for business (Narver and Slater, 1990). Market Orientation (MO) is a knowledge-based intangible resource, which ensures the provision of higher value to customers (Vega-Vázquez et al., 2016). Market orientation (MO) contributes most strongly to performance compared to alternative strategic orientations such as innovation, learning, and entrepreneurial orientation (Grinstein, 2008). This is supported by (Ho and Spillan, 2010), which states MO allows companies to immediately respond to changes in the market by presenting new products and services.

Market orientation consists of three dimensions, namely customer orientation, competitor orientation, and interfunctional coordination (Narver and Slater, 1990). Customer orientation requires business owners to understand buyers, so as to create superior value for them continuously (Narver and Slater, 1990). Customer orientation emphasizes the role of understanding target customers, by analyzing the needs and desires of their customers (Zhou et al., 2007). Customer-oriented companies can develop and maintain close relationships with customers and get fast feedback from them (Zhou and Li, 2010). Customer orientation influences company performance by increasing customer commitment and loyalty and increasing company innovation and quality (Osman, 2014). Competitor orientation focuses on understanding and responding to competitors 'strategies and focus on matching their competitors' marketing initiatives (Zhou et al., 2007). Competitor orientation also refers to understanding the weaknesses and strengths of competitors, providing superior value to customers, and defeating competitors (Kumar et al., 2011; Hussain et al., 2015). Competitor orientation also refers to the company's understanding of current and potential competitors regarding their strengths and weaknesses as well as their long-term capabilities and strategies (Osman, 2014).

MO is conceptualized as an organizational culture, which efficiently provokes superior market value creation behavior and subsequently improves business performance (Ngo and O'Cass, 2012). The facts show that market-oriented companies tend to have more new business opportunities and have better performance than companies that are not marketoriented so that these companies are superior in competition and grow in terms of profit and market share (Armstrong et al., 2014). (Talaja et al., 2017) state that the MO represents strategic competencies that increase better utilization of market-based assets/resources, and the MO directly and indirectly (through VRIN resources) increases competitive advantage and that competitive advantage leads to higher levels of company performance. Another opinion from (Narver and Slater, 1990) states that market orientation provides a positive relationship to business profitability. Meanwhile, according to (Kumar et al., 2011), Marketoriented corporate culture is considered a key to improving business performance because it prioritizes customer needs and focuses on customer satisfaction. Another opinion from (Gruber-Muecke and Hofer, 2015) states that the creation of superior customer value is also attributed to improved performance and is the key to competitive advantage and performance. Therefore according to (Buli, 2017), SME Managers need to be encouraged to be involved in the MO to respond to customer requests and realize business performance goals.

According to (Protcko and Dornberger, 2014) and (Lekmat et al., 2018), MO is positively related to the performance of SMEs. (Buli, 2017) also found that MO was an important factor for SME performance. However, (Shehu and Mahmood, 2014) failed to 
find a direct relationship between $\mathrm{MO}$ and SME performance. Another opinion from (Njeru and Kibera, 2016) states that market orientation (MO) has been recognized by scholars and practitioners as the main key related to thinking about modern marketing methods, and one of the determinants of superior company performance, and a key source of competitive advantage. Based on the theoretical framework and relevant research findings regarding the relationship between market orientation and SME performance, one hypothesis can be built. Hypothesis 2: Market orientation has positive effect on SME Performance.

\section{METHODOLOGY}

The research design uses primary data with a survey sample in DKI Jakarta, Indonesia and focuses on SMEs as respondents through questionnaires distributed online using Google Forms. The sampling method used is the Non Probability Sampling method, with the criteria used to select the sample are owners/managers of SME businesses of management level or higher, in DKI Jakarta, Indonesia and SMEs that have been running for two years. Testing is done using Smart PLS software 3.3.2.

Entrepreneurial Orientation will be measured using nine items, developed by (Covin and Slevin, 1989) which contains three dimensions, namely, Innovativeness, Proactiveness, and Risk-Taking as in the research of (Ali et al., 2020). A total of nine items measured will undergo a small modification of sentence changes to make it easier to understand. Whereas Market Orientation will be measured using the MKTOR scale, which was adapted from (Narver and Slater, 1990) and only uses two dimensions, namely Customer Orientation and Competitor Orientation as in the study of (Najmi and Abror, 2019). A total of ten items measured will undergo a small modification of sentence changes to make it easier to understand. To measure the performance of SMEs (SME Firm Performance), use subjective measurements based on respondents' perceptions about Sales Growth, Profit Growth, Employment Growth, Market Share Growth (Murni, 2017). The measurement of Entrepreneurship Orientation, Market Orientation, and Firm Performance (SME Performance) will use the Ordinal 1-10 scale, where this scale shows ( 1 = Strongly Disagree; $10=$ Strongly Agree).

Research data is quantitative, and the data will be analyzed by Outer Model test, to test the validity and reliability of the relationship of variables with their latent variables through the Convergent Validity Test, Discriminant Validity Test, Reliability Test, and Cross Loading Test; and the Inner Model test, to test the relationship between latent variables through the Coefficient of Determination and the Goodness of Fit Test (Ghozali and Latan, 2014). Then the next stage is testing the hypothesis for each research variable using the T-test with boostrapping.

\section{THE RESULTS OF STATISTICAL TESTS}

Two hundred and twenty (220) self-administered questionnaires distributed, and the number of data returned was two hundred and seven (207) questionnaires from entrepreneurs and SME managers at the managerial level and above in DKI Jakarta. From two hundred and seven (207) questionnaires returned, only 190 data were filled out completely and could be tested, because the data is incomplete to be filled. 
Figure 2. Convergent Validity Test Loading Factor Results

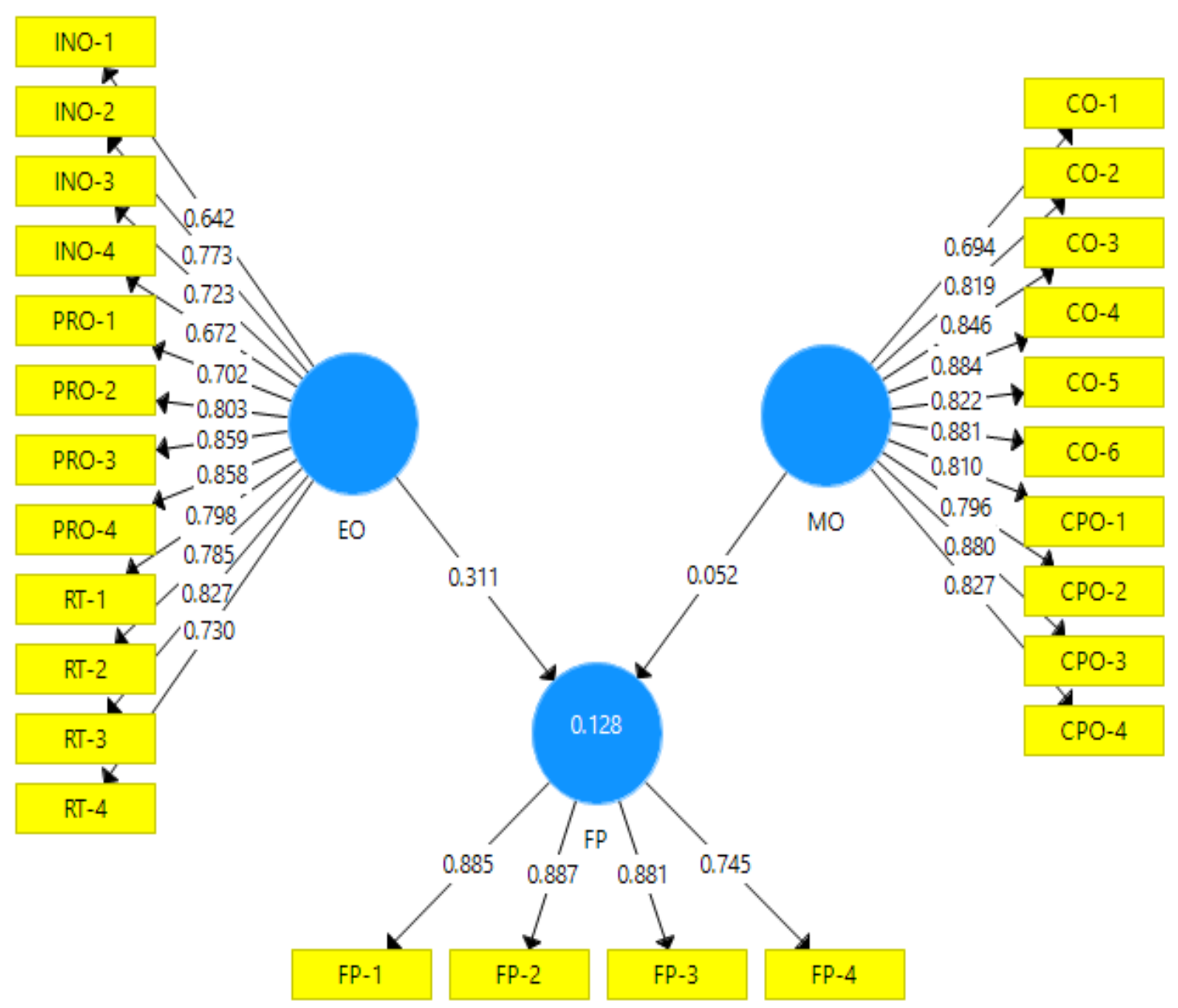

Figure 2 shows the results of convergent validity tests (Path Coefficient) which explains that all indicators on the variable Entrepreneurial Orientation (EO), Market Orientation (MO), and Firm Performance (FP) have a Loading Factor value > 0.6. This means that the indicators measuring of all have valid, so that all indicators can be used for further analysis. To strengthen the convergent validity test results, a disveriminant validity test with cross loading is performed. Discriminant validity test results are presented in Table 1. Based on the results shown in Table 1, each indicator on the Entrepreneurial Orientation (EO), Market Orientation (MO), and Firm Performance (FP) variables has the largest Cross Loading value on the variable it forms compared to other variables. Therefore, the indicators used in the study have fulfilled discriminant validity. 
Table 1. Discriminant Validity Test with Cross Loading

\begin{tabular}{|c|c|c|c|}
\hline Indikator & $\begin{array}{c}\text { Entrepreneurial } \\
\text { Orientation }\end{array}$ & Market Orientation & Firm Performance \\
\hline INO - 1 & 0.642 & 0.527 & 0.180 \\
\hline INO - 2 & 0.773 & 0.707 & 0.249 \\
\hline INO - 3 & 0.723 & 0.581 & 0.202 \\
\hline INO - 4 & 0.672 & 0.527 & 0.205 \\
\hline PRO - 1 & 0.702 & 0.675 & 0.178 \\
\hline PRO - 2 & 0.803 & 0.692 & 0.320 \\
\hline PRO - 3 & 0.859 & 0.778 & 0.313 \\
\hline PRO - 4 & 0.858 & 0.756 & 0.328 \\
\hline RT - 1 & 0.798 & 0.732 & 0.269 \\
\hline RT - 2 & 0.785 & 0.755 & 0.252 \\
\hline RT - 3 & 0.827 & 0.702 & 0.411 \\
\hline RT - 4 & 0.730 & 0.749 & 0.223 \\
\hline $\mathrm{CO}-1$ & 0.537 & 0.694 & 0.155 \\
\hline $\mathrm{CO}-2$ & 0.667 & 0.819 & 0.212 \\
\hline $\mathrm{CO}-3$ & 0.702 & 0.846 & 0.216 \\
\hline $\mathrm{CO}-4$ & 0.786 & 0.884 & 0.276 \\
\hline $\mathrm{CO}-5$ & 0.654 & 0.882 & 0.203 \\
\hline $\mathrm{CO}-6$ & 0.795 & 0.881 & 0.300 \\
\hline CPO - 1 & 0.763 & 0.810 & 0.285 \\
\hline $\mathrm{CPO}-2$ & 0.772 & 0.796 & 0.259 \\
\hline CPO - 3 & 0.776 & 0.880 & 0.365 \\
\hline $\mathrm{CPO}-4$ & 0.813 & 0.827 & 0.331 \\
\hline FP - 1 & 0.326 & 0.290 & 0.885 \\
\hline FP - 2 & 0.308 & 0.286 & 0.887 \\
\hline FP - 3 & 0.310 & 0.279 & 0.881 \\
\hline FP - 4 & 0.270 & 0.265 & 0.745 \\
\hline
\end{tabular}

Table 2 was the results of the reliability test with the Cronbach's Alpha, Composite Reliability, and AVE tests. From the three test equipment, the values of each variable were obtained: Cronbach's Alpha value> 0.7 Composite Reliability value> 0.7. and AVE> 0.5. This value meets the criteria of the test equipment (Hair et al., 2014), thus all research variables are declared reliable. R-Square value for Firm Performance is 0.128 or $12.8 \%$. This shows that the Entrepreneurial Orientation (EO) and Market Orientation (MO) variables can explain the Firm Performance variable by $12.8 \%$, while the remaining $100 \%$ $-12.8 \%=87.2 \%$ are explained by other variables outside this study. Table 2 presents the Goodness of Fit test, the results obtained NFI values closer to 1.0, so that the model is said to be Fit. The value of Goodness of Fit using equation (1). The results of the Goodness of Fit $(\mathrm{GoF})$ test $=0.292038$. This value is classified as medium (Wetzels et al., 2009).

$$
\mathrm{GoF}=\sqrt{R^{2} x \overline{A V E}}
$$


Table 2. Reliability Test \& Inner Model (Determination Coefficient and Goodness of Fit)

\begin{tabular}{c|c|c|c|c|c|c|c}
\hline Variabel & $\begin{array}{c}\text { Cronbach's } \\
\text { Alpha }\end{array}$ & $\begin{array}{c}\text { Composite } \\
\text { Reliability }\end{array}$ & AVE & $\begin{array}{c}\text { R } \\
\text { Square }\end{array}$ & $\overline{\boldsymbol{A V E}}$ & NFI & $\begin{array}{c}\text { Goodness } \\
\text { of Fit }\end{array}$ \\
\hline $\begin{array}{c}\text { Entrepreneurial } \\
\text { Orientation }\end{array}$ & 0.936 & 0.945 & 0.589 & & & & \\
\cline { 1 - 3 } $\begin{array}{c}\text { Firm } \\
\text { Performance }\end{array}$ & 0.872 & 0.913 & 0.685 & 0.128 & 0,66633 & 0.834 & 0.292038 \\
\cline { 1 - 3 } $\begin{array}{c}\text { Market } \\
\text { Orientation }\end{array}$ & 0.949 & 0.956 & 0.725 & & & & \\
\hline
\end{tabular}

Table 3 shows the results of hypothesis testing on the performance of SMEs. the value of the path coefficients in the Market Orientation and Entrepreneurial Orientation variables towards Firm Performance were positive.

Table 3. t-test Inner Model

\begin{tabular}{lccc}
\hline Variabel & Path Coefficient & t-statistics & p-values \\
\hline Entrepreneurial Orientation $\rightarrow$ Performance & 0.311 & 2.101 & 0.036 \\
Market Orientation $\rightarrow$ Performance & 0.052 & 0.364 & 0.716 \\
\hline
\end{tabular}

Table 3 also shows that the first Hypothesis (H1) was not rejected because (t-statistic $=2.101>1.96 ; \mathrm{p}$-value $=0.036<0.05)$. Therefore, Entrepreneurial Orientation has positive effect on Firm Performance and the second Hypothesis (H2) is rejected because (t-statistic $=0.364<1.96 ; \mathrm{p}$-value $=0.716>0.05)$. Market Orientation has no effect on Firm Performance at DKI Jakarta SMEs

\section{DISCUSSION}

Based on the results of testing the research hypothesis, it can be seen that Entrepreneurial Orientation (EO) has positive effect on SME Performance on SME owners / managers in DKI Jakarta. Better Entrepreneurial Orientation will be able to improve the performance of SME. The Entrepreneurship Orientation encourages SME owners to continue to innovate in order to increase sales and continue to attract customers. Performance can be maintained and improved through management policies that continuously proactively introduce the new products at every opportunity to consumers, because proactive indicators (PRO-3 and PRO-4) make the greatest contribution of all indicators of the EO variable. Proactively done while maintaining and improving and being a pioneer in terms of sales services to consumers (PRO-3) and improving the ability to use technology (PRO-4) before competitors do.

This supports previous research by (Jogaratnam, 2018) which states that EO creates distinct benefits for SMEs through the ability to innovate and take advantage of opportunities for competitive advantage, which will result in better performance. This result is in accordance with (Najmi and Abror, 2019), which states that SMEs that have a proactive attitude will continue to take advantage of opportunities by continuing to look for market needs and desires through the selection of appropriate strategies and produce good business performance. However, this opinion is contrary to the opinion of (Solikahan and 
Mohammad, 2019), which states that SMEs generally do not consider the strategies used, and focus more on profit alone, so that in their business activities do not use Entrepreneurship Orientation (EO) as the basis for making and taking decision.

The results of this study are consistent with the results of the study (Borshalina, 2015; Matthias et al., 2016; Hussain et al., 2017; Aladejebi et al., 2018; Ali et al., 2020), which state that there is positive Entrepreneurial Orientation effect on SME Performance. However, the results of this study are not appropriate and contradict the results of research from (Affendy et al., 2015) and (Solikahan and Mohammad, 2019), which states that there is no effect of Entrepreneurial Orientation on SME Performance.

In addition, based on the results of testing the research hypothesis, it can be seen that the Market Orientation variable does not affect SME Performance on SME business owners/managers in DKI Jakarta. This is in accordance with (Octavia and Ali, 2017) which states that small businesses such as SMEs, are not always customer-oriented and competitors-oriented, because SME entrepreneurs lack motivation to win the competition and rarely do market analysis to find out the target market. Failure to encourage market orientation because most SMEs in Indonesia tend to position the company as a follower in market competition. Some even position it as a filler in a small portion of the market where competitors are difficult to enter the market. Another reason, winning market competition requires the ability to research product development. This requires a relatively large source of funds. Funding at SME'S in Indonesia is a classic problem that continues to be repeated all the time. This is an input for the government to take bold policies so that SMEs develop and become the backbone of strong and independent economic actors.

Male SME managers tend to open businesses without having preliminary \& thorough planning and open a business just to establish relationships (networking) and increase degrees. While women SME managers tend to open businesses so they have more flexible work time to take care of the family. This opinion is supported by Solikahan \& Mohammad (2019), who stated that SMEs tend to be more passive in marketing their products and do not implement any strategy to increase their market share, so that their business performance does not improve. In addition, it can also be concluded that the selection of the right strategy and market analysis will influence company policies and the selection of the types of products to be sold to suit the market's desires so as to make SME entrepreneurs more profitable. Choosing the right strategy can also make SME entrepreneurs not need to compete in a market environment that is already dominated by large companies or overcrowded markets, resulting in a price war that will affect the large profits that will be obtained by SME entrepreneurs.

The results of this study are consistent with the results of research conducted by (Kajalo and Lindblom, 2015), (Octavia and Ali, 2017) and (Solikahan and Mohammad, 2019), who stated that there was no effect of Market Orientation on SME Performance. However, the results of this study were not appropriate and contrary to the results of research conducted by (Amin et al., 2016), (Masa'deh et al., 2018), (Najmi and Abror, 2019), (Rashid et al., 2019), and (Ali et al., 2020) which states that there is an influence of Market Orientation on SME Performance. 


\section{CONCLUSION}

The results of this study indicate that Entrepreneurship Orientation affects Firm Performance in SMEs and there is no influence between Market Orientation and Company Performance. In a competitive business environment, companies need to implement Entrepreneurial Orientation, in order to determine the company's strategic direction to develop products and services at the right time to meet current market needs and customer needs. In addition, it can also be concluded that the results of this study can provide important insights on improving the performance of SMEs in developing countries such as Indonesia. The results of this study will increase the knowledge of managers and owners of SMEs in order to improve the performance of their companies, in order to stay afloat, grow, and gain profits in a competitive business environment. A competitive business environment brings many challenges to a company, therefore it can be concluded how important it is for companies to implement Entrepreneurial Orientation.

Limitation of the Study and Implications for Future Research. Future studies must (i). added the number of samples to be tested because the number of SMEs that are widespread and spread in DKI Jakarta still cannot be thoroughly examined due to the influence of the COVID-19 pandemic, which caused the government to issue a Large Scale Social Limiting Policy (PSBB) in DKI Jakarta making it difficult to collect data (ii) focus is broadly examining other variables that can affect the relationship between EO, MO and SME company performance, due to the large R-Square value that is still low in this study. Other variables as a link (mediation or moderation) that have been used in other studies such as, Product Quality mediation variables (Yang and Ju, 2017), Customer Engagement mediation variables (Al Mamun et al., 2018), mediating variables Financial Capital (Financial Capital) and Export Market Turbulence (Boso et al., 2016), mediating variables Responsive attitude in decision making (Decision Responsiveness) (Rashid et al., 2019). (iii) extend the observation year to 5 years, other than because this study was affected by the COVID-19 pandemic which affected the performance of all SMEs in DKI Jakarta, but also because it was able to obtain a more complete picture of company performance and (iv) not only use Subjective measurements but also use objective measurements to measure performance, although SME performance is usually the owner's performance because the SME owner also acts as the manager of SME, so there is no agency cost and influence in measuring SME performance.

\section{REFFERENCES}

Affendy, A. H., Asmat-Nizam, Abdul-Talib, and Farid, M. . (2015). Entrepreneural Orientation effects on Market Orientation and SMEs Business Performance - A SEM Approach. Review of Integrative Business and Economics, 4(3), 259-271.

Ahmad, A., Supian, K., Farina, I., Yunus, M., Tanius, E., Ishak, B., and Yunus, M. (2019). Entrepreneurial Orientation and Hospitality Performance: the Mediating Effect of Market Orientation. J. Acad. Corp. Stud., 7(1), 61-71.

Aladejebi, O. A., Great, T., and Clinic, B. (2018). Predictors of firm performance among selected SMEs in Lagos, Nigeria Predictors of firm performance among selected SMEs in Lagos , Nigeria. International Journal of Applied Research, 4(June), 8-17. 
Ali, G. A., Hilman, H., and Gorondutse, A. H. (2020). Effect of entrepreneurial orientation, market orientation and total quality management on performance: Evidence from Saudi SMEs. Benchmarking International Journal, 27(4), 1503-1531.

Alvarez-Torres, F. J., Lopez-Torres, G. C., and Schiuma, G. (2019). Linking entrepreneurial orientation to SMEs' performance: Implications for entrepreneurship universities. Management Decision, 57(12), 3364-3386.

Amin, M., Thurasamy, R., Aldakhil, A. M., and Kaswuri, A. H. Bin. (2016). The effect of market orientation as a mediating variable in the relationship between entrepreneurial orientation and SMEs performance. Nankai Business Review International, 7(1), 3959.

Amit, R., and Schoemaker, P. J. H. (1993). Strategic assets and organizational rent. Strategic Management Journal, 14(1), 33-46.

Balodi, K. C. (2019). Strategic orientations and performance of young ventures: Moderating role of environmental turbulence. Management Decision, 58(4), 666-686.

Barney, J. (1991). Firm Resources and Sustained Competitive Advantage. Journal of Management, 17(1), 99-120.

Borshalina, T. (2015). The Effect of Entrepreneurial Orientation on Business Performance Moderated by Innovation Creativity ( Study on Trusmi Batik SMEs in Cirebon, West Java, Indonesia ). Iicies.

Boso, N., Oghazi, P., Cadogan, J. W., and Story, V. M. (2016). Entrepreneurial and marketoriented activities, financial capital, environment turbulence, and export performance in an emerging economy. Journal of Small Business Strategy, 26(1Special Issue), 124.

Buli, B. M. (2017). Entrepreneurial orientation, market orientation and performance of SMEs in the manufacturing industry: Evidence from Ethiopian enterprises. Management Research Review, 40(3), 292-309.

Campos, H. M., and Valenzuela, F. A. A. (2013). The Relationship between Entrepreneurial Orientation, Time Orientation and Small Business Performance: Evidence from Mexico. Revista Da Micro e Pequena Empresa, 7(1), 48-63.

Covin, J. G., and Slevin, D. P. (1989). Strategic Management of Small Firms in Hostile and Benign Environments. Strategic Management Journal, 10(1), 75-87.

DeepaBabu, K., and Manalel, J. (2016). Entrepreneurial Orientation And Firm Performance : A Critical Examination. IOSR Journal of Business and Management, 18(4), 21-28.

Ferraresi, A. A., Quandt, C. O., dos Santos, S. A., and Frega, J. R. (2012). Knowledge management and strategic orientation: Leveraging innovativeness and performance. Journal of Knowledge Management, 16(5), 688-701.

Ferreira, J., and Garrido Azevedo, S. (2008). Entrepreneurial orientation (EO) and growth of firms: key lessons for managers and business professionals. Problems and Perspectives in Management, 6(1), 82-88.

Grinstein, A. (2008). The relationships between market orientation and alternative strategic orientations: A meta-analysis. European Journal of Marketing, 42(1-2), 115-134.

Gruber-Muecke, T., and Hofer, K. M. (2015). Market orientation, entrepreneurial orientation and performance in emerging markets. International Journal of Emerging Markets, 10(3), 560-571.

Ho, M. C. H., and Spillan, J. E. (2010). The journey from market orientation to firm 
performance: A comparative study of US and Taiwanese SMEs. Management Research Review, 33(5), 472-483.

Hussain, J., Abbas, Q., and Khan, M. A. (2017). Entrepreneurial Orientation and Performance within Firm: The Moderating Effect of Market Orientation. Global Management Journal for Academic \& Corporate Studies, 7(1), 9-18.

Hussain, J., Khan, A., and Shah, F. A. (2015). The Impacts of Entrepreneurial Orientation on Organizational Performance: Study of Pakistani SMEs. Sarhad Journal of Management Sciences, 1(1), 52-64.

Jatmika, R. T. D. (2016). Masalah yang dihadapi Usaha Kecil Menengah di Indonesia. ElEcosy: Jurnal Studi Ekonomi Syariah, 2(6), 13.

Jensen, M., and Meckling, W. (1976). Theory of The Firm: Managerial Behaviour, Agency Costs And Ownership Structure. Journal of Financial Economics, 3(4), 305-360.

Jogaratnam, G. (2018). Human Capital, Organizational Orientations and Performance: Evidence From the Restaurant Industry. International Journal of Hospitality and Tourism Administration, 19(4), 416-439.

Kajalo, S., and Lindblom, A. (2015). Market orientation, entrepreneurial orientation and business performance among small retailers. International Journal of Retail and Distribution Management, 43(7), 580-596.

Keh, H. T., Nguyen, T. T. M., and Ng, H. P. (2007). The effects of entrepreneurial orientation and marketing information on the performance of SMEs. Journal of Business Venturing, 22(4), 592-611.

Khalili, H., nejadhussein, syyedhamzeh, and Fazel, A. (2013). The influence of entrepreneurial orientation on innovative performance. Journal of Knowledge-Based Innovation in China, 5(3), 262-278.

Kirca, A. H., Jayachandran, S., and Bearden, W. O. (2005). Market orientation: A metaanalytic review and assessment of its antecedents and impact on performance. Journal of Marketing, 69(2), 24-41.

Kocak, A., Carsrud, A., and Oflazoglu, S. (2017). Market, entrepreneurial, and technology orientations: impact on innovation and firm performance. Management Decision, 55(2), 248-270.

Kumar, M., Antony, J., and Tiwari, M. K. (2011). Six Sigma implementation framework for SMEs-a roadmap to manage and sustain the change. International Journal of Production Research, 49(18), 5449-5467.

Lekmat, L., Selvarajah, C., and Hewege, C. (2018). Relationship between Market Orientation, Entrepreneurial Orientation, and Firm Performance in Thai SMEs: The Mediating Role of Marketing Capabilities. International Journal of Business and Economics, 17(3), 213-237.

Lonial, S. C., and Carter, R. E. (2015). The impact of organizational orientations on medium and small firm performance: A resource-based perspective. Journal of Small Business Management, 53(1), 94-113.

Lumpkin, G. ., and Dess, G. (2001). Linking Two Dimensions of Entrepreneurial Orientation to Firm Performance : The Moderating Role of Environment and Industry Life Cycle. Journal of Business Venturing, 16, 429-451.

Lumpkin, G. T., and Dess, G. G. (1996). Clarifying the entrepreneurial orientation construct and linking it to performance. Academy of Management Review, 21(1), 135-172.

Mamun, A. Al, Mohiuddin, M., Fazal, S. A., and Ahmad, G. Bin. (2018). Effect of 
entrepreneurial and market orientation on consumer engagement and performance of manufacturing SMEs. Management Research Review, 41(1), 133-147.

Martin, S. L., and Javalgi, R. R. G. (2016). Entrepreneurial orientation, marketing capabilities and performance: The Moderating role of Competitive Intensity on Latin American International New Ventures. Journal of Business Research, 69(6), 20402051.

Masa'deh, R., Al-Henzab, J., Tarhini, A., and Obeidat, B. Y. (2018). The associations among market orientation, technology orientation, entrepreneurial orientation and organizational performance. Benchmarking, 25(8), 3117-3142.

Mason, M., Floreani, J., Miani, S., Beltrame, F., and Cappelletto, R. (2015). Understanding the Impact of Entrepreneurial Orientation on Smes' Performance. the Role of the Financing Structure. Procedia Economics and Finance, 23(December), 1649-1661.

Matchaba-Hove, T. M., and Vambe, A. K. (2014). Entrepreneurial Orientation and Performance of Small Businesses in the Retail Sector in the Eastern Cape Province of South Africa. Journal of Marketing, 5(2), 12-39.

Matthias, E. E., Agwu, A.-N. E., and Onyeizugbe, C. U. (2016). Entrepreneurial Orientation and Performance of Small and Medium Scale Enterprises in Ebonyi State. International Journal in Management and Social Science, 04(05), 300-312.

Miller, D. (1983). The correlates of entrepreneurship in three types of firms. Management Science, 29(7), 770-792.

Montiel-Campos, H. (2018). Entrepreneurial orientation and market orientation: Systematic literature review and future research. Journal of Research in Marketing and Entrepreneurship, 20(2), 292-322.

Murni, T. (2017). The Effect of Entrepreneurial Orientation to Low Cost Strategy, Differentiation Strategy, Sustainable Innovation and Performance of Small and Medium Enterprises (Studies at Batik Small and Medium Enterprises in East Java Province, Indonesia). 9(20).

Najmi, and Abror. (2019). The Effect Of Entrepreneurial Orientation, Market Orientation, Business Network Ability And Product Innovation On Performance (Study in Small and Micro Enterprises of Food in Padang). 97(Piceeba), 619-636.

Narver, J. C., and Slater, S. F. (1990). The Effect of a Market Orientation on Business Profitability. Journal of Marketing, 54(4), 20-35.

Ngo, L. V., and O'Cass, A. (2012). Creating superior customer value for B2B firms through supplier firm capabilities. Industrial Marketing Management, 41(1), 125-135.

Nguyen, N. P. (2018). Performance implication of market orientation and use of management accounting systems. Journal of Asian Business and Economic Studies, 25(1), 33-49.

Njeru, W. G., and Kibera, F. N. (2016). Marketing Practices, Market Orientation and Performance of Tour Firms In Kenya: A Mediated Approach. 6(4), 33-49.

Nuari, A. R. (2017). Pentingnya Usaha Kecil Menengah (Ukm) Untuk Mendorong Pertumbuhan Ekonomi. Journal of Chemical Information and Modeling, 53(9), 16891699.

Octavia, A., and Ali, H. (2017). International Review of Management and Marketing The Model of Market Orientation, Entrepreneurial Orientation and Business Performance of Small and Medium Enterprises. International Review of Management and Marketing, 7(3), 331-337. http:www.econjournals.com 
Omisakin, O. M., Nakhid, C., Littrell, R., and Verbitsky, J. (2016). Entrepreneurial Orientation among Migrants and Small and Medium Enterprises. Journal of Business Administration Research, 5(1), 7-22.

Osman, J. (2014). An Empirical Investigation into the Significance of Intellectual Capital and Strategic Orientations on Innovation Capability and Firm Performance in Malaysian Information and Communications Technology ( ICT ) Small-to-Medium Enterprises (SMEs). March, 233.

Peteraf, M. A., and Bergen, M. E. (2003). Scanning dynamic competitive landscapes: A market-based and resource-based framework. Strategic Management Journal, 24(10 SPEC ISS.), 1027-1041.

Protcko, E., and Dornberger, U. (2014). The impact of market orientation on business performance - The case of Tatarstan knowledge-intensive companies (Russia). Problems and Perspectives in Management, 12(4), 225-231.

Rashid, M. A., Kalyar, M. N., and Shafique, I. (2019). Market orientation and womenowned SMEs performance: The contingent role of entrepreneurial orientation and strategic decision responsiveness. South Asian Journal of Business Studies.

Rauch, A., Wiklund, J., Lumpkin, G. T., and Frese, M. (2009). Entrepreneurial orientation and business performance: An assessment of past research and suggestions for the future. Entrepreneurship: Theory and Practice, 33(3), 761-787.

Rezaei, J., and Ortt, R. (2018). Entrepreneurial orientation and firm performance: the mediating role of functional performances. Management Research Review, 41(7), 878-900.

Riviezzo, A., Napolitano, M. R., and Garofano, A. (2013). Entrepreneurial orientation and market orientation in SMEs: An explorative study. In Conceptual Richness and Methodological Diversity in Entrepreneurship Research (Issue January).

Runyan, R. C., Huddleston, P., and Swinney, J. (2006). Entrepreneurial orientation and social capital as small firm strategies: A study of gender differences from a resourcebased view. International Entrepreneurship and Management Journal, 2(4), 455477.

Sahibzada Jawad, S. U. R., Naushad, S., Yousaf, S., and Yousaf, Z. (2019). Exploring performance of software houses: Market orientation and mediating role of firm innovativeness. World Journal of Entrepreneurship, Management and Sustainable Development, 16(1), 1-11.

Sahoo, S., and Yadav, S. (2017). Entrepreneurial orientation of SMEs, Total Quality Management and Firm performance. Journal of Manufacturing Technology Management, 28(7), 892-912.

Semrau, T., Ambos, T., and Kraus, S. (2016). Entrepreneurial orientation and SME performance across societal cultures: An international study. Journal of Business Research, 69(5), 1928-1932.

Shehu, A. M., and Mahmood, R. (2014). Market orientation and firm performance among nigerian SMEs: The moderating role of business environment. Mediterranean Journal of Social Sciences, 5(23), 158-164.

Solikahan, E. Z., and Mohammad, A. (2019). Entrepreneurial Orientation, Market Orientation and Financial Orientation in Supporting the Performance of Karawo SMEs in Gorontalo City. Journal of Applied Management (JAM), 17(4), 729-740.

Talaja, A., Miočević, D., Alfirević, N., and Pavičić, J. (2017). Market Orientation, 
Competitive Advantage and Business Performance: Exploring the Indirect Effects. Drustvena Istrazivanja, 26(4).

Vega-Vázquez, M., Cossío-Silva, F. J., and Revilla-Camacho, M. Á. (2016). Entrepreneurial orientation-hotel performance: Has market orientation anything to say? Journal of Business Research, 69(11), 5089-5094.

Wang, Y. (2016). What are the biggest obstacles to growth of SMEs in developing countries? - An empirical evidence from an enterprise survey. Borsa Istanbul Review, 16(3), 167-176.

Wernerfelt, B. (1984). Harmonised implementation of Application-Specific Messages (ASMs). Strategic Management Journal, CINCO(2), 1-12.

Westover, J. (2008). The Record of finance: The effectiveness/Ineffectiveness of Microfinance Programs as a Means of alleviating Poverty. Electronic Journal of Sociology, 1(12), 1-8.

Wetzels, M., Odekerken-Schröder, G., and Van Oppen, C. (2009). Using PLS path modeling for assessing hierarchical construct models: Guidelines and empirical illustration. MIS Quarterly: Management Information Systems, 33(1), 177-196.

Wiklund, J., and Shepherd, D. (2003). Knowledge-based resources, entrepreneurial orientation, and the performance of small and medium-sized businesses. Strategic Management Journal, 24(13), 1307-1314.

Wiklund, J., and Shepherd, D. (2005). Entrepreneurial orientation and small business performance: A configurational approach. Journal of Business Venturing, 20(1), 7191.

Wolff, J. A., Pett, T. L., and Ring, J. K. (2015). Small firm growth as a function of both learning orientation and entrepreneurial orientation: An empirical analysis. International Journal of Entrepreneurial Behaviour and Research, 21(5), 709-730.

Yadav, S. K., Tripathi, V., and Goel, G. (2019). Modelling strategic orientation dimensions and performance of small and medium enterprises: An application of interpretative structural modelling. Journal of Modelling in Management, 14(3), 754-772.

Yang, Y., and Ju, X. F. (2017). Entrepreneurial Orientation and Firm Performance: Is Product Quality a Missing Link? Entrepreneurship Research Journal, 8(1), 1-13.

Zhou, K., and Li, J. J. (2010). How foreign firms achieve competitive advantage in the Chinese emerging economy: Managerial ties and market orientation. Journal of Business Research, 63(8), 856-862.

Zhou, L., Wu, W. P., and Luo, X. (2007). Internationalization and the performance of bornglobal SMEs: The mediating role of social networks. Journal of International Business Studies, 38(4), 673-690. 